підвищення частки молодих плазмоцитів та зниження чисельності зрілих гранулоцитів у гемолімфі, що може бути пов'язане з їх міграцією у тканини для залучення до процесу фагоцитозу пошкоджених клітин в умовах підвищеного стресового. Що стосується нітритного азоту, то тут навпаки гемоцитарний індекс змістився у бік типово гранулярних форм, що можливо пов'язано із численними ушкодженнями тканин та необхідністю великої кількості пулу гранулярних клітин в репаративних процесах у Daphnia magna.

\title{
Література:
}

1. Metchnikoff I. A disease of Daphnia caused by a yeast. In: Brock T., editor. A contribution to the theory of phagocytes as agents for attack on disease-causing organisms. Milestones in Microbiology. American Society for Microbiology; Washington D.C. 1884. P. 132-138.

2. Auld S.K., Scholefield J.A., Little T.J. Genetic variation in the cellular response of Daphnia magna (Crustacea: Cladocera) to its bacterial parasite. Proceedings of the Royal Society of London. Series-B: Biological Sciences. 2010. P. 3291-3297.

DOI https://doi.org/10.30525/978-9934-26-183-1-11

\section{ДОСЛІДЖЕННЯ ЗАКОНОМІРНОСТЕЙ ЕЛЕКТРОХІМІЧНОГО УТВОРЕННЯ КОАГУЛЯНТІВ ДЛЯ ОЧИСТКИ СТІЧНИХ ВОД}

\author{
Макаров С. О. \\ ад'юнкт \\ Національний університет цฺивільного захисту України \\ м. Харків, Україна
}

При використанні анодів 3 металів відбувається електролітичне розчинення з переходом у розчин іонів металів, які згодом утворюють коагулянти - нерозчинні гідроксиди металів. Новоутворені коагулянти мають підвищену адсорбційну активність до колоїдних і завислих частинок і використовуються у процесах електрокоагуляційної очистки стічних вод. При електрокоагуляції стічних вод можуть протікати інші електрохімічні, фізико-хімічні та хімічні процеси, які відбуваються у наступній послідовності: електрофоретичне концентрування (спрямований рух дисперсій як вільно заряджених частинок і концентрування 
їх біля поверхні електродів); електролітичне розчинення анодів та утворення гідроксидів металів; поляризаційна коагуляція дисперсних частинок; упаковка первинних агрегатів і флокуляційна коагуляція; флотація утворених агрегатів бульбашками електролітичних газів. Всі ці процеси забезпечують високий ступінь очистки забруднених стічних вод у різних фазово-дисперсних станах.

На процес електрохімічного утворення коагулянтів впливає багато факторів: матеріал розчинених анодів, кількість анодів в електролізері, $\mathrm{pH}$ середовища, сила току, наявність у стічних водах інших електролітів, електрична напруга, тривалість процесу електрокоагуляції тощо [1-6]. Ефективність електрокоагуляції зазвичай оцінюється за ступенем очистки стічних вод від конкретного виду забруднень, які характеризуються певним показником, наприклад, хімічне споживання кисню (ХСК), кількість етеророзчинних речовин, кількість зважених речовин тощо.

В роботі [1] електрокоагуляцію стічних вод молокозаводів проводили 3 використанням алюмінієвих електродів та ефективність процесу оцінювали за величиною ХСК та кількістю зважених речовин. Встановлено, що при початковому $\mathrm{pH} \approx 5$ стічної води, при щільності електричного струму $61.6 \mathrm{~A} / \mathrm{m}^{2}$, який було застосовано протягом 21 хвилини, ХСК знизилось на 57\%,а загальна кількість зважених речовин знизилась на 97\%. При цьому, рН обробленої (очищеної) стічної води підвищився до 10.

В роботі [6] вивчали електрокоагуляцію стічних вод виробництва пальмової олії. Встановлено, що оптимальна кількість алюмінієвих електродів для максимального очищення стічних вод від барвників дорівнює 4, оптимальна напруга дорівнює 15 В. При цьому кількість доданого електроліту $\mathrm{NaCl}$ для найбільшої ефективності процесу очищення дорівнює 1.67 г/л.

В роботі [7] автори досліджували електрокоагуляційну обробку стічних вод підприємства по переробці паперу. Ефективність процесу визначали за наступними показниками стічної води: хімічне споживання кисню (ХСК), кількість зважених речовин, кількість аміаку та кольоровість. Для підвищення ефективності видалення забруднювачів, в електролізері використовувалась комбінація 3 чотирьох вертикально розташованих електродів, в якій два - залізні розташовувались між двома алюмінієвими електродами. Визначено вплив тривалості процесу електрокоагуляції, електричної напруги та початкового рН стічної води на ефективність очистки стічних вод від вищезазначених забруднювачів. Встановлено, що оптимальними параметрами електрокоагуляції $\epsilon$ величина електричної напруги $10 \mathrm{~B}$, початковий рН стічної води 7 та тривалість процесу - 60 хвилин. За цих умов ефективність видалення 
ХСК, зважених речовин, кольоровості та аміаку складає $79.5 \%, 83.4 \%$, $98.5 \%$ та $85.3 \%$ відповідно.

Авторами [8] були проведені експерименти з електрокоагуляційної очистки стічних вод виробництва оцтової кислоти. Облаштування лабораторної установки складалось 3 трьох вертикально розташованих алюмінієвих та трьох залізних електродів, з яких три були катодом і три - анодом. Досліджувалась порівняльна характеристика двох випадків: алюмінієві електроди - аноди та залізні електроди - аноди. Катодами, відповідно були залізні або алюмінієві електроди. За технологією в стічні води додавались додаткові хімічні реагенти - натрій сульфат для підвищення електропровідності, а також високомолекулярні полімерні речовини органічної і неорганічної природи для покращення процесу коагуляції. Було вивчено вплив щільності електричного струму, величини $\mathrm{pH}$ та природи добавки на ефективність процесу електрокоагуляції стічних вод. Встановлено, що в разі застосування алюмінієвих анодів, щільності струму $20 \mathrm{~mA} / \mathrm{cm}^{2}$ та вихідного $\mathrm{pH} \mathrm{4,} \mathrm{було} \mathrm{досягнуто} \mathrm{90,91 \%} \mathrm{видалення} \mathrm{ХСК.} \mathrm{При} \mathrm{цьому} \mathrm{на} \mathrm{обробку}$ було витрачено 42,42 кВт.год/м ${ }^{3}$ електричної енергії. Встановлено, що у випадку використання залізних анодів, щільності струму $22.5 \mathrm{~mA} / \mathrm{cm}^{2}$, вихідного $\mathrm{pH} 9$, без будь-яких хімічних добавок видалення ХСК досягає 93,58\%. На обробку було витрачено 47,06 кВт·год/м ${ }^{3}$ електричної енергії.

В багатьох наукових працях вивчались також процеси електрохімічного утворення коагулянтів [8-12]. Основні хімічні реакції утворення алюміній гідроксиду, що відбуваються в процесі електрокоагуляції стічних вод наступні (в разі алюмінієвих анодів):

- на алюмінієвих анодах окислення алюмінію $\mathrm{Al}_{(\text {тв })} \rightarrow \mathrm{Al}^{3+}{ }_{(\mathrm{p})}+3 \mathrm{e}$;

- на катодах відновлення води $3 \mathrm{H}_{2} \mathrm{O}+3 \mathrm{e} \rightarrow 3 / 2 \mathrm{H}_{2}$ (г) $\uparrow+3 \mathrm{OH}_{(\mathrm{p})}^{-}$;

- утворення коагулянту в кислому або нейтральному середовищі:

$\mathrm{Al}^{3+}{ }_{(\mathrm{p})}+3 \mathrm{H}_{2} \mathrm{O} \rightarrow \mathrm{Al}(\mathrm{OH})_{3 \text { (тв) }} \downarrow+3 \mathrm{H}_{(\mathrm{p})}^{+}$;

- утворення коагулянту в лужному середовищі:

$\mathrm{Al}^{3+}{ }_{(\mathrm{p})}+3 \mathrm{OH}^{-}{ }_{(\mathrm{p})} \rightarrow \mathrm{Al}(\mathrm{OH})_{3(\text { тв })} \downarrow$.

Як стверджують автори робіт [2, 6, 9-11], в лужному середовищі утворюються мономерні $\mathrm{AlOH}^{2+}, \mathrm{Al}(\mathrm{OH})_{2}{ }^{+}, \mathrm{Al}(\mathrm{OH})_{4}{ }^{-}$та полімерні $\mathrm{Al}_{2}(\mathrm{OH})_{2}{ }^{4+}, \quad \mathrm{Al}_{2}(\mathrm{OH})_{5}{ }^{+}, \quad \mathrm{Al}_{6}(\mathrm{OH})_{15^{3+}}, \quad \mathrm{Al}_{13}(\mathrm{OH})_{34^{5+}}$ тощо алюмінієві комплекси, які здатні підвищувати ефективність електрокоагуляції завдяки тому, що мають як позитивні, так і негативні заряди. Однак, експериментальні дані $[8,12]$ показують, що підвищення вихідного значення $\mathrm{pH}$ стічних вод може, навпаки, зменшити ефективність електрокоагуляції. При цьому, як стверджують автори [8], при рН>7 на алюмінієвому аноді утворюється гелевий шар, який уповільнює процеси окиснення i, відповідно, утворення коагулянту. 
Отже, встановлено, що ефективність електрохімічного утворення коагулянтів (гідроксидів металів) для електрокоагуляційного очищення стічних вод молокозаводів безпосередньо залежить від умов проведення процесу, а саме, кислотності вихідних стічних вод, наявності різних забруднювачів, сили або щільності електричного струму, тривалості проведення експерименту. Як з'ясувалось, механізм утворення коагулянтів в середовищах 3 різним показником $\mathrm{pH}, \epsilon$ не до кінця вивченим, особливо, електрохімічного утворення коагулянтів на основі алюмінію. Тому дослідження хіміко-технологічних параметрів електрохімічного одержання коагулянту на основі алюмінію для електрокоагуляційного очищення стічних вод молокопереробних підприємств є важливою науково-практичною задачею.

\section{Література:}

1. Valente G.-F. S., Mendonca R.-C. S., Pereira J.-A. M. The efficiency of electrocoagulation using aluminum electrodes in treating wastewater from a dairy industry. Ciencia Rural. Santa Maria. 2015. 45, 9. P. 1713-1719.

2. Chezeau B., Boudriche L., Vial C., Boudjemaa A. Treatment of dairy wastewater by electrocoagulation process: Advantages of combined iron/aluminum electrodes (published online 15.07.2019). Separation Science and Technology. 15. 2019.

3. Aitbara A., Cherifi M., Hazourli S. and Leclerc J.-P. Continuous treatment of industrial dairy effluent by electrocoagulation using aluminum electrodes. Desalination and Water Treatment. 57, 8. 2016. P. 3395-3404.

4. Benaissa F., Kermet-Said H. and Moulai-Mostera N. Optimization and kinetic modeling of electrocoagulation treatment of dairy wastewater. Desalination and Water Treatment. 57, 13. 2016. P. 5988-5994.

5. Varank G., Sabuncu M. E. Application of central composite design approach for dairy wastewater treatment by electrocoagulation using iron and aluminum electrodes: modeling and optimization. Desalination and Water Treatment. 56, 1. 2015. P. 33-54.

6. Shariff I., Nur Syuhaidah M. A., Borhannuddin A., Yahaya H., Megat Ahmad K.-M. H., Application of electrocoagulation process for decolourisation of palm oil mill effluent. Nature Environment and Pollution Technology. 17, 4. 2018. P. 1267-1271.

7. Izadi A., Hosseini M., Darzi G. N., Bidhendi G. N., Shariati F. P., Treatment of paper-recycling wastewater by electrocoagulation using aluminum and iron electrodes. Journal of Environmental Heals Science and Engineering. 16. 2018. P. 257-264.

8. Yilmaz S., Estra Gerek E., Yavuz Y., Koparal A. S. Treatment of vinegar industry wastewater of electrocoagulation with monopolar aluminum 
and iron electrodes and toxicity evaluation. Water Science \& Technology. 2019. P. 1-11.

9. Quaissa Y. A., Chabani M., Amrane A. and Bensmaili A. Removal of tetracycline by electrocoagulation: Kinetic and isotherm modeling through adsorption. Journal of Environmental Chemical Engineering. 2, 1. 2014. P. 177-184.

10. Marugananthan M., Bhaskar Raju G., Prabhakar S. Separation of pollutants from tannery effluents by electro flotation. Separation and Purification Technology. 40, 1. 2004. P. 69-75.

11. Zongo I., Maiga A. H., Wethe J., Valentin G., Leclerc J. P., Paternotte G., Lapicque F. Electrocoagulation for the treatment of textile wastewaters with $\mathrm{Al}$ or Fe electrodes: compared variations of COD levels, turbidity and absorbance. Journal of Hazardous Materials. 169, 1-3. 2009. P. 70-76.

12. Changmai M., Pasawan M., Purkait M. K. Separation and purification technology treatment of oily wastewater from drilling site using electrocoagulation followed by microfiltration. Separation and Purification Technology. 210. 2019. P. 463-472.

DOI https://doi.org/10.30525/978-9934-26-183-1-12

\section{ВПЛИВ ІОНІВ МІДІ НА ПАРОСТКИ ЯЧМЕНЮ}

Січняк О. Л.

кандидат біологічних наук, дочент, доиент кафедри генетики та молекулярної біології Одеський національний університет імені I. I. Мечникова

Мірось С. Л.

кандидат біологічних наук, дочент, доиент кафедри генетики та молекулярної біології Одеський національний університет імені I. I. Мечникова

Білоконь С. В.

кандидат біологічних наук, дочент, доиент кафедри генетики та молекулярної біології Одеський національний університет імені I. I. Мечникова м. Одеса, Украӥна

Останнім часом проблема забруднення довкілля стала глобальною. Широке використання фунгіцидів, які містять мідь, призводить до іiі 46 